\title{
Literature Review on Influencing Factors of Audit Fees
}

\author{
Xin Ye \\ Department of Accounting, School of Management, Jinan University, Guangzhou, China \\ Email: CheGuevaraZlq@163.com
}

How to cite this paper: Ye, X. (2020). Literature Review on Influencing Factors of Audit Fees. Modern Economy, 11, 249-260. https://doi.org/10.4236/me.2020.112022

Received: December 27, 2019

Accepted: February 2, 2020

Published: February 5, 2020

Copyright (C) 2020 by author(s) and Scientific Research Publishing Inc. This work is licensed under the Creative Commons Attribution International License (CC BY 4.0).

http://creativecommons.org/licenses/by/4.0/

\begin{abstract}
Audit fee refers to the remuneration obtained by accounting firms and auditors for providing professional services. The determination of audit fees requires mutual consultation between audited units and accounting firms. In order to ensure the quality of the audit report, as an important part of the auditor incentive mechanism, the establishment of reasonable audit fees is a necessary condition to ensure that the certified public accountants perform the normal information assurance function and ensure the effective operation of the audit work. Audit fee is the price of audit report. As the supplier of audit report and the demander of audit report, the relationship between supply and demand of both parties will inevitably affect audit fee. Therefore, this paper mainly from two aspects-from the perspective of accounting firms to investigate the impact of audit fees and the impact of customers' perspective on audit fees to sort out the relevant literature on audit fees in these two aspects, hoping to provide reference value for the study of audit fees.
\end{abstract}

\section{Keywords}

Audit Fees, Influencing Factors, Literature Review

\section{Introduction}

Audit fee refers to the remuneration obtained by accounting firms and auditors for providing professional services. The determination of audit cost requires mutual consultation between the audited unit and the accounting firm. In order to ensure the quality of the audit report, as an important part of the auditor incentive mechanism, the establishment of reasonable audit fees is a necessary condition to ensure that the certified public accountants perform the normal information assurance function and ensure the effective operation of the audit work. And scientific and reasonable audit fees can encourage auditors to cor- 
rectly perform their duties, effectively supervise listed companies, and ensure the effective operation of the capital market. However, if audit fees can't provide effective incentives, or even cover audit costs, then the independent audit will not be able to send the right signals to the market, thus damaging the vital interests of the public.

The earliest research on audit fees is Simunic. He divides the factors affecting audit fees into two categories: one is audit cost, that is, audit input; the other is audit risk compensation. In his research, he also analyzed the reasons why large firms charge high audit fees. He believes that due to scale economy, product heterogeneity hypothesis and market dominance, large firms get audit premium higher than average yield (Simunic, 1980).

Hay divides the influencing factors of audit cost into three categories: customer attribute variable, accounting firm attribute variable and audit contract attribute variable (Hay et al., 2006). From the perspective of accounting firms, this paper examines the impact of audit fees and the impact of customers on audit fees.

\section{The Impact of Accounting Firms on Audit Fees}

1) The Impact of Firm Size on Audit Fees

When the scale of the accounting firm becomes larger and larger, on the one hand, the division of its functions will become more and more specific, improving work efficiency, and the allocation of the same fixed cost in each department will be reduced, thus reducing the cost; on the other hand, the quality of audit services provided will also be different, and high-quality audit services will inevitably charge high audit fees. In addition, large-scale accounting firms will pay attention to their own brand value. In order to avoid litigation compensation, when necessary human and material resources cannot reduce audit risk, they may also choose to collect risk premium to compensate for the possible losses in the future.

Simunic divides accounting firms into "Big Eight" and "No Big Eight" according to their size. It is found that no matter the size of accounting firms, there is no obvious difference in the fees charged to all customers, that is, the audit market has a competitive function, and there is no reputation premium in the audit fees collected by auditors from listed companies (Simunic, 1980). However, on the contrary, Francis also classified the accounting firms according to Simunic's classification. However, the study found that the "Big Eight" accounting firms would charge high audit fees to listed companies in Australia (Francis, 1984). Francis et al. have integrated the conclusions of the two literatures and come to the conclusion that in the listed companies with smaller assets, the "Big Eight" can provide differentiated services; while the "Big Eight" will not charge audit premium for the listed companies with larger assets, and there is no difference with the audit fee charged by the "Big Eight" (Francis \& Stokes, 1986). Beatty takes IPO company as the research object, and finds that the scale of accounting firm and the audit fee charged are significantly in the 
same direction (Beatty, 1993). From the above research results, we can find that when considering the impact of the size of accounting firms on audit fees, we need to pay attention to the asset size differences of listed companies, because most of the studies have found that large-scale accounting firms will charge higher audit fees for small-scale listed companies.

Chinese scholars also have relevant research. Liu et al. take the data of Listed Companies in Shanghai and Shenzhen in 2001 as the research object, and find that there is no significant difference between large-scale accounting firms in China and small-scale accounting firms in charging audit fees, which is not the same as the results of foreign research, and then draw the conclusion that the audit provided by large-scale accounting firms in China The audit quality is not necessarily better than that provided by local small-scale accounting firms (Liu, Ye, \& Liao, 2003). The possible reason is that scale economy effect and "deep pocket" effect are mutually offset. However, Lei et al. and Zhang found that the audit fees charged by the international "Big Four" auditors were significantly higher than those charged by the Chinese local accounting firms, but the author only studied the audit premium of the international "Big Four" accounting firms, and did not make a comparative study on the different scale accounting firms in China (Lei \& Guo, 2007; Qi, Chen, \& Zhang, 2004). Therefore, it is uncertain whether the audit premium is caused by scale premium or reputation premium. Lv et al. classified accounting firms into "Big Four", Chinese capital "Big Ten" and other small-scale firms to test whether there is scale premium. It is found that the "Big Four" charge audit premium to the top 20\% of listed companies and the bottom $20 \%$ of listed companies, while the "Big Ten" of Chinese capital only charge audit premium to the small-scale listed companies, while other types of accounting firms do not charge audit premium (Lv \& Song, 2007).

2) The Impact of Firm reputation on Audit Fees

Generally speaking, the better the reputation of an accounting firm, the higher the audit fees charged. The higher the quality of audit services, the more reliable the information provided to the users of statements. Listed companies are more willing to pay higher than average audit fees to accounting firms with higher reputation. From another point of view, in order to avoid the risk of material misstatement and thus affect the reputation of the firm, the firm with high reputation will inevitably increase the audit investment, which will also lead to the increase of audit costs. The research of Bandyopadhyay et al. shows that listed companies are willing to pay higher audit fees for high-quality audit services provided by high-quality accounting firms, so audit fees increase (Bandyopadhyay \& Kao, 2001). Audoussetcoulier S. employed two independent accounting firms (joint audit) to take advantage of the unique audit environment in France. The research results show that after controlling the size of audit clients, business complexity, audit risk and other factors, compared with employing one of Big Four accounting firms and one of the smaller accounting firms, two accounting firms were employed Big Four accounting firms do not need to pay higher audit 
fees, that is, joint reputation does not increase audit fees (Audoussetcoulier, 2015). Wang et al. used Chinese Institute of Certified Public Accountants's top 20 accounting firms in 2012 to influence the audit fees of the same client before and after joining the "non-Big Four" international accounting firms. The results showed that the audit fees of the accounting firms joining the "non-Big Four" international accounting firms were higher than those of the non-joining international accounting firms (Wang \& Xie, 2015).

\section{The Impact of Customers on Audit Fees}

1) The Impact of Customer Size on Audit Fees

Simunic uses the total assets of audit units to measure the scale of assets and the complexity of business. Empirical research shows that unit total assets are significantly positively related to audit fees, and unit total assets are important factors determining audit fees (Simunic, 1980). Taylor et al. applied the modified Simunic model to the UK audit market research, and the research results were consistent with Simunic, and the model interpretation ability was increased from $49 \%$ to $79 \%$, which proved once again that the size and complexity of the audited units were significantly positively related to the audit fees (Taylor \& Baker, 1981).

In terms of the correlation between the size of the assets of the audited units and the audit fees, the empirical research results in China are relatively uniform, and they all believe that the larger the size of the assets of the audited units, the higher the audit fees. Wu Lina takes the natural logarithm of the total assets of the audit unit as the measurement index to represent the company size. Empirical research shows that the size of the company has a significant positive impact on the annual financial audit fees $(\mathrm{Wu}, 2003)$. Wang et al. also represented the scale of the audit company by the total assets of the audited unit, and obtained the consistent results through the correlation test (Wang \& Liu, 2007).

2) The Impact of Customer's Complexity on Audit Fees

Krishnagopal et al. by studying 1980-1997 audit data, it is found that audit fees have a certain relationship with accounts receivable and inventory, although the coefficient in the model has a downward trend, but the relationship is still significant. However, some scholars have different results (Krishnagopal \& David, 2001). Firth and Low et al. respectively studied the audit market of New Zealand and Singapore respectively. The empirical results show that there is no obvious correlation between audit fees and business complexity. For this result, some scholars think that it is due to the difference between companies and subsidiaries in each research market, which has independence and complexity, and the number of subsidiaries can't completely replace the complexity of enterprises. Therefore, the mainstream research still believes that there is a positive correlation between the size and complexity of the audited units and the audit fees (Firth, 1985; Low, Tan, \& Koh, 1990).

In terms of the relationship between business complexity and audit fees, the results will vary according to the way of measurement taken. Cai Jifu used the 
ratio of accounts receivable to total assets and the ratio of company inventory to total assets to reflect the complexity of economic business. The empirical results only show a significant positive correlation with the audit fees, while the latter is positively related to audit fees but not significant (Cai, 2007). Chen et al. also obtained the same results from the study of A-share listed companies in 2007-2013 (Chen \& Xu, 2013). He and Chen took the proportion of the sum of inventory and accounts receivable in total assets as an alternative variable to study the relationship between the sum of inventory and accounts receivable and the audit fees. The results showed that the positive correlation was not significant (He \& Liu, 2015; Chen, Yang, \& Zhang, 2016). Wang et al. believe that the number of subsidiaries of listed companies can represent the complexity of business. The empirical results show that the more subsidiaries, the higher audit fees of listed companies (Wang, Zhang, \& Yang, 2010).

3) The Impact of Customer's Property on Audit Fees

The property right of the company will affect the agency cost of the company. Liu et al. use the data of Chinese listed companies to find that the audit fees paid by state-owned listed companies are significantly lower than those paid by private listed companies (Liu \& Liu, 2013). Li Mincai conducted a study based on the data of Listed Companies in China's small and medium-sized board, and found that he was more inclined to choose auditors with social capital of the development and Audit Commission, and needed to pay a premium of about $10 \%$ for the social capital of auditors (Li, 2013). The research results of Wang Hong show that in the IPO audit project of high-risk private enterprises, the ratio of audit fees to investment banking fees will increase significantly, but in the IPO project of high-risk state-owned enterprises, the impact will be weakened (Wang, 2012). The research of Chen et al. found that generally, the higher the tax avoidance degree of private listed companies is, the higher the audit fees they pay. In a better legal environment, the tax avoidance of private enterprises is restrained, and there is no significant difference in the audit premium caused by tax avoidance between state-owned listed companies and private listed companies (Chen \& Luo, 2015).

4) The Impact of Customer's Risk on Audit Fees

Among all the items in the audit report, the biggest risk is inventory and accounts receivable. Therefore, the existing research often uses inventory, accounts receivable or the proportion of the two in total assets to measure the risk, and the empirical conclusions are contradictory. The research of Schelleman et al. shows that the complexity and scale of the business of listed companies are the main factors affecting audit expenses, and there is no significant relationship between inventory and accounts receivable and audit expenses (Schelleman \& Knechel, 2010). Zhang et al. used the regression analysis of the proportion of external guarantee amount in total assets, the proportion of accounts receivable in total assets and the proportion of inventory in total assets of listed companies, and found that there was a significant positive correlation between the amount of external guarantee and audit fees, and there was a significant positive correla- 
tion between accounts receivable and audit fees, but there was no significant relationship between inventory and audit fees (Zhang, Chen, \& Wu, 2005).

Some literatures study the influence of financial risk on audit fees, and financial risk has a significant positive relationship with audit fees. Simunic research shows that the profitability of customers can reflect the potential loss of the company to a certain extent. It is generally believed that clients with weak profitability will make accounting firms face greater risks, so audit fees will increase accordingly (Simunic, 1980). Schelleman et al. found that whether the loss of customers was significantly positively related to the audit fees (Schelleman \& Knechel, 2010). Zhang et al. showed that the maturity of corporate debt was negatively correlated with audit fees, and the asset-liability ratio was positively correlated with audit fees (Zhang \& Wang, 2011). The research of Han et al. shows that companies with significant changes in performance pay higher audit fees than companies without significant changes in performance (Han \& Zhou, 2013).

5) The Impact of Earnings Management on Audit Fees

When there is earnings manipulation in an enterprise, certified public accountants must reevaluate the risk of the enterprise. The greater the risk, the more complex the audit procedures need to be implemented, and the greater the allocation of resources such as human and material resources invested. The audit risk and litigation risk faced by the firm will inevitably lead to the increase of audit fees. There is a significant positive correlation between earnings management and audit fees. The earnings quality of the company will decrease with the increase of audit fees. Frankel et al. studied the earnings quality of enterprises from the perspective of non-audit payment. After testing, it was found that when the earnings quality of enterprises is poor, the financial statements are usually whitewashed based on the transfer of good business conditions and their own interests to the outside world, and then the phenomenon of collusion with the firms is covered up by paying non-audit payment. The higher the fees, the worse the quality of earnings is (Frankel, Johnson, \& Nelson, 2002). Fatima added the new variable $\mathrm{CFO}$ compensation mechanism after verifying the positive correlation between the two, and found that the variable has a positive regulatory effect on the correlation between the two, that is, when the bonus of CFO increases, it can enhance the relationship between earnings management and audit fees (Alali, 2011).

Liu et al. found that compared with the performance compensation commitment before, after signing the performance compensation commitment, the audit fees of listed companies significantly increased. Further research shows that when the target company adopts share compensation, the level of corporate governance is low, and the target company and the listed company are related parties, the positive effect of merger and acquisition; a performance compensation commitment on audit fees is more significant. In addition, they found that earnings management is the intermediary factor of merger and acquisition; a performance compensation commitment that affects audit fees, that is, perfor- 
mance compensation commitment will lead to earnings management behavior of the company, and then improve audit fees (Liu, Sun, \& Yuan, 2018). Zhang et al. found that abnormal audit fees have a significant positive impact on the level of classified transfer of earnings management; when the ability of enterprises to be audited by non "Big Four" firms, to manipulate accruals is limited or located in areas with high level of rule of law, the above-mentioned positive impact is more significant (Zhang, Xiong, \& Zeng, 2019). Zhang et al. mainly studied the correlation between audit fees and earnings management. By selecting the data of China's A-share listed companies in 2009 as the initial sample, using the Simunic audit fee model, they found that there was a positive correlation between them. In addition, the larger the company's asset size, the increased probability of being issued standard audit opinions and the firm the larger the scale, the higher the audit fees (Zhang \& Song, 2011). Jiang et al. found that: Earnings Management measured by accruals has a strong correlation with audit fees; at the same time, the study added factors such as the size of the company's assets and the size of accounting firms to analyze, the results show that they also have a significant positive correlation with audit fees (Jiang \& Yu, 2016).

6) The Impact of Internal Control on Audit Fees

After SOX404 act was promulgated, western scholars' research conclusions on internal control and audit fees are basically the same. Reviewing the previous research conclusions, we can find that internal control defects are positively related to audit fees level. The research of Raghunandan et al. shows that internal control defects can lead to audit fees premium. In 2004, the audit fees of the company that disclosed the substantive internal control defects is $43 \%$ higher than that of the company that did not make relevant disclosure (Raghunandan \& Rama, 2006). On the basis of previous studies, Rani et al. further tested the relationship between internal control deficiencies and audit fees. The paper found that the first year after the implementation of Section 404 of SOX act, the research showed that the existence of internal control deficiencies led to higher audit fees. Rani et al. found that the annual audit fees remained at a relatively high level after the occurrence of internal control defects. They classified internal control defects into general defects and company specific defects according to different contents of internal control defects, and classified internal control defects into major defects and important defects according to the impact of internal control defects on internal control. On this basis, they have systematically explored the relationship between the types of internal control defects and the level of audit fees. The empirical results show that the audit fees are positively related to the severity of internal control defects. In addition, their research also shows that even though the internal control of listed companies does not constitute a defect according to the provisions of article 404, if there is a defect in internal control according to the disclosure requirements of article 302, the company will still face higher audit fees. It is also found that companies that disclose internal control deficiencies under article 302 will face higher audit fees even if they do not disclose internal control deficiencies in subsequent years 
(Hoitash, Hoitash, \& Bedard, 2008).

The research on the relationship between internal control defects and audit fees by Chinese scholars started late, but some progress has been made. The research conclusions of Chinese scholars on this issue are basically the same, that is, the quality of internal control of companies that disclose internal control defects is low, and the audit fees are high. According to Ji Wei's research, when an enterprise has internal control defects, the auditors will charge more audit fees; the higher the degree of internal control defects, the higher the audit fees will correspondingly increase; the audit fees of "Big Four" firms are higher than those of other domestic accounting firms (Ji, 2019). Gai et al. used the data of Chinese Listed Companies in 2009 and 2010 to test the impact of internal control defects on audit fees from cross-section and cross period perspectives. It is found that the internal control defects of listed companies will lead to the increase of audit fees. Compared with general internal control defects, the effect of specific internal control defects on audit fees is more significant. Further study found that the rectification of internal control defects of enterprises with internal control defects can reduce the audit fees of accounting firms, but the effect is not significant. This proves that the reduction of internal control defects and the more effective implementation of internal control system have an impact on the reduction of audit fees (Gai \& Sheng, 2013).

7) The Impact of Corporate Governance on Audit Fees

Carcello et al. found that the governance structure of the board of directors has a significant positive correlation with audit fees, and also has a significant positive correlation with the independence, diligence and professionalism of the board of directors (Carcello, Hermanson, Neal, \& Riley, 2002). Khalil et al. conducted an empirical study on the audit fees of Canadian listed companies and found that the separation of two powers was positively correlated with audit fees (Khalil, Magnan, \& Cohen, 2011). Beasley et al. found that the proportion of independent directors was significantly positively correlated with audit fees in the study of the relationship between corporate governance structure and audit fees. The possible reason is that the enterprises with higher independent directors also have higher demand for audit quality. Therefore, when choosing a business office, they will choose the enterprises with higher reputation, and the audit fees will also increase (Beasley \& Petroni, 2011). However, Jiang et al. have studied the relationship between the separation of two powers and the audit fees, and found that when the chairman and the general manager become one, the audit fees will become higher. The reason for the difference may be that the foreign separation system of two powers is relatively perfect, which increases the company's demand for high audit quality, so the audit fees increases. However, the separation system of two powers in China is not perfect. When the two powers are combined into one, the supervisory role of the board of directors will be weakened. Therefore, the auditor will improve the estimation of risk control during the audit, resulting in the increase of audit fees (Jiang \& Zheng, 2012). Li et al. found that the audit committee's professionalism is conducive to reducing 
the audit fees of listed companies. CEO power will interfere with the effective play of the audit committee's professional role and weaken its negative impact on audit fees. Further research found that compared with state-owned enterprises, non-state-owned enterprises' CEO power will further weaken the negative impact of audit committee's professionalism on audit fees (Li, Wang, \& Yin, 2017). Yang Hua selected the data of Listed Companies in the chemical industry as a sample to study the relationship between corporate governance, political relevance and audit fees. It was found that the size of independent directors, the diligence of the board of directors and audit fees in the corporate governance structure were significantly positively correlated (Yang, 2015).

\section{Conclusion}

This paper systematically combs the research of audit fees from two aspects of clients and firms, which is helpful to deepen the understanding of audit fees and find new research ideas of audit fees. However, due to the limitations of the author's research ability and the length of the article, there are still some deficiencies. This paper only collates the research on the influencing factors of clients and firms, and fails to systematically sort out all the research on audit expense literature.

Based on the above discussion, we find that the western academic research on audit fees is very comprehensive and has formed a wealth of research results. However, there are some shortcomings in the academic circles of our country.

China's economic environment is quite different from that of western countries. If we directly transplant the empirical conclusions of foreign countries to China, it will be lack of persuasion. With the development of capital market, the research abroad undoubtedly provides certain theoretical basis and research method for the study of audit fees in China. Therefore, there is a large research space in this field, and the future research direction mainly includes the following points:

1) Combine theory with practice. Compared with developed countries, there are some deficiencies in the supervision and management of audit fees in China. Therefore, it is of theoretical and practical significance to explore the impact of supervision on audit fees.

2) Fully consider the factors that affect the audit fees. The uncertainty of economic environment will affect the operation and financial decision-making of enterprises. Therefore, it is of great significance to explore the impact of the uncertainty of economic environment on audit fees.

\section{Conflicts of Interest}

The author declares no conflicts of interest regarding the publication of this paper.

\section{References}

Alali, F. (2011). Audit Fees and Discretionary Accruals: Compensation Structure Effect. 
Managerial Auditing Journal, 26, 90-113.

https://doi.org/10.1108/02686901111094994

Audoussetcoulier, S. (2015). Audit Fees in a Joint Audit Setting. European Accounting Review, 24, 347-377. https://doi.org/10.1080/09638180.2014.892787

Bandyopadhyay, S. P., \& Kao, J. L. (2001). Competition and Big 6 Brand Name Reputation: Evidence from the Ontario Municipal Audit Market. Contemporary Accounting Research, 18, 27-64. https://doi.org/10.1506/JWFM-24F5-2KQG-AV37

Beasley, M. S., \& Petroni, K. R. (2011). Board Independence and Audit-Firm Type. Social Science Electronic Publishing, 20, 97-114. https://doi.org/10.2139/ssrn.137582

Beatty, R. (1993). The Economic Determinants of Audit Compensation in the Initial Public Offerings Market. Journal of Accounting Research, 31, 294-302. https://doi.org/10.2307/2491275

Cai, J. F. (2007). Research on the Relationship between Corporate Governance, Audit Risk and Audit Costs. Auditing Research, 3, 65-71.

Carcello, J. V., Hermanson, D. R., Neal, T. L., \& Riley, R. A. (2002). Board Characteristics and Audit Fees. Contemporary Accounting Research, 19, 365-384. https://doi.org/10.1506/CHWK-GMQ0-MLKE-K03V

Chen, D., \& Luo, Y. (2015). Does Tax Avoidance Affect Audit Pricing. Economic Management Journal, 37, 98-109.

Chen, J., Yang, X. D., \& Zhang, Z. H. (2016). Environmental Uncertainty, Corporate Social Responsibility and Audit Fees. Auditing Research, 4, 61-66.

Chen, Z., \& Xu, H. (2013). The Auditor Industry Expertise, Brand Reputation and Auditing Costs. Journal of Shanxi Finance and Economics University, 35, 114-124.

Firth, M. (1985). An Analysis of Audit Fees and Their Determinants in New-Zealand. Auditing: A Journal of Practice and Theory, 4, 23-37.

Francis, J. R. (1984). The Effect of Audit Firm Size on Audit Prices: A Study of the Australian Market. Journal of Accounting and Economics, 6, 133-151.

https://doi.org/10.1016/0165-4101(84)90010-7

Francis, J. R., \& Stokes, D. J. (1986). Audit Prices, Product Differentiation, and Scale Economics: Further Evidence from the Australian Market. Journal of Accounting Research, 24, 393-393. https://doi.org/10.2307/2491141

Frankel, R. M., Johnson, M. F., \& Nelson, K. K. (2002). The Relation between Auditor's Fees for Non-Audit Services and Earnings Quality. Research Papers, 77, 71-105.

https://doi.org/10.2308/accr.2002.77.s-1.71

Gai, D., \& Sheng, C. Y. (2013). The Influence of Internal Control Defects and Its Correction on Audit Fees: Data from A-Share Listed Companies in China. Journal of Audit and Economics, 28, 21-27.

Han, X. M., \& Zhou, W. (2013). Customer Performance Fluctuation and Audit Risk Prevention: Information Assurance or Insurance Function. Accounting Research, 9, 71-77+97.

Hay, D. C., Knechel, W. R., \& Wong, N. (2006). Audit Fees: A Meta-Analysis of the Effect of Supply and Demand Attributes. Contemporary Accounting Research, 23, 141-191. https://doi.org/10.1506/4XR4-KT5V-E8CN-91GX

He, W. F., \& Liu, W. (2015). Company Managers' Capabilities and Audit Fees. Accounting Research, 1, 82-89.

Hoitash, R., Hoitash, U., \& Bedard, J. C. (2008). Internal Control Quality and Audit Pricing under the Sarbanes-Oxley Act. Auditing: A Journal of Practice and Theory, 27, 105-126. https://doi.org/10.2308/aud.2008.27.1.105 
Ji, W. (2019). Internal Control Defects and Audit Fees. Economic Research Guide, 15, 101-104+115.

Jiang, C. H., \& Zheng, J. X. (2012). Correlation Test between Corporate Governance and Audit Fees: Data from Shanghai and Shenzhen A-Share Stock Market in 2010. Research of Finance and Education, 25, 44-50.

Jiang, X. H., \& Yu, P. (2016). Research on the Impact of Enterprise Earnings Management on the Audit Fees of Accounting Firms-Evidence from the Audit Fee Disclosure of Listed Companies in Jiangsu and Zhejiang. Communication of Finance and Accounting, 33, 15-18.

Khalil, S. K., Magnan, M., \& Cohen, J. R. (2011). Dual-Class Shares and Audit Pricing: Evidence from the Canadian Markets. Social Science Electronic Publishing, 27, 199-216.

Krishnagopal, M., \& David, D. W. (2001). Long-Term Trends in Audit Fees. Auditing: A Journal of Practice \& Theory, 20, 115-136. https://doi.org/10.2308/aud.2001.20.1.115

Lei, J. Y., \& Guo, Q. (2007). Empirical Research on the Impact of Firm Size and Organization Form on Audit Fees-Evidence from Shanghai and Shenzhen in 2005. Communication of Finance and Accounting (Academy Version), 12, 104-106.

Li, M. C. (2013). Does Issuing the Social Capital of the Audit Committee Affect Audit Demand and Audit Fees?-Empirical Evidence from IPOs of Small and Medium Boards. Journal of Audit \& Economics, 28, 50-59.

Li, Y., Wang, F. F., \& Yin, T. X. (2017). CEO Power, Audit Committee Professionalism and Audit Fees. Auditing Research, 6, 91-98.

Liu, B., Ye, J. Z., \& Liao, Y. Y. (2003). Empirical Research on the Influencing Factors of Auditing Costs of Chinese Listed Companies-Empirical Evidence from Shenzhen and Shanghai 2001 Annual Reports. Audit Research, 1, 44-47.

Liu, X. Q., Sun, J., \& Yuan, R. L. (2018). Merger and Acquisition; A Performance Compensation Commitment and Audit Fees. Accounting Research, 12, 70-76.

Liu, X., \& Liu, F. (2013). Arrangement of Control Rights, Firm Pricing Strategies and Audit Quality: Evidence from A-Share Markets. Research on Economics and Management, 8, 99-107.

Low, L. C., Tan, P. H., \& Koh, H. C. (1990). The Determination of Audit Fees: An Analysis in the Singapore Context. Journal of Business Finance and Accounting, 17, 285-295. https://doi.org/10.1111/j.1468-5957.1990.tb00561.x

Lv, Z. D., \& Song, C. (2007). Research on the Scale Premium of Accounting Firms. Journal of Shanxi Finance and Economics University, 12, 113-119.

Qi, J. N., Chen, H. L., \& Zhang, Y. (2004). The Size, Brand, Price and Audit Quality of the Firm-Study on the Charge and Quality of the International "Big Four" Chinese Audit Market. Audit Research, 3, 59-65.

Raghunandan, K., \& Rama, D. V. (2006). Sox Section 404 Material Weakness Disclosures and Audit Fees. Auditing: A Journal of Practice and Theory, 25, 99-114. https://doi.org/10.2308/aud.2006.25.1.99

Schelleman, C., \& Knechel, W. R. (2010). Short-Term Accruals and the Pricing and Production of Audit Services. Auditing: A Journal of Practice \& Theory, 29, 221-250. https://doi.org/10.2308/aud.2010.29.1.221

Simunic, D. A. (1980). The Pricing of Audit Services: Theory and Evidence. Journal of Accounting Research, 22, 161-190. https://doi.org/10.2307/2490397

Taylor, M. E., \& Baker, R. L. (1981). An Analysis of the External Audit Fee. Accounting and Business Research, 4, 55-60. https://doi.org/10.1080/00014788.1981.9728789 
Wang, B., Zhang, J., \& Yang, D. M. (2010). Research on the Long-Term Characteristics of Influencing Factors of Audit Fees. Journal of Shanxi Finance and Economics University, 32, 110-115.

Wang, H. (2012). Benefit Distribution of Accounting Firms and Underwriters in the Process of IPO. Collected Essays on Finance and Economics, 6, 64-71.

Wang, S. P., \& Xie, J. (2015). Effects of Joining Non-Big Four International Accounting Companies on Audit Pricing of Accounting Firms. Journal of Social Science of Hunan Normal University, 44, 114-119.

Wang, X. R., \& Liu, L. J. (2007). Relevance Research on Auditing Costs and Its Influencing Factors. China Price, 10, 53-56.

Wu, L. N. (2003). Empirical Analysis of the Impact of Earnings Management on Audit Fees-Evidence from the First Audit Fee Disclosure of Chinese Listed Companies. Accounting Research, 12, 39-44.

Yang, H. (2015). Corporate Governance, Political Connection and Audit Fees: Empirical Evidence from Listed Companies in China's A-Share Chemical Industry from 2011 to 2013. Public Finance Research, 8, 107-112.

Zhang, J. X., Chen, Y., \& Wu, X. (2005). Analysis of the Impact of Risk Factors on Audit Fees of Listed Companies in China: Data from Shanghai Annual Report 2003. Audit Research, 4, 34-38.

Zhang, Q. Y., \& Song, Y. H. (2011). Empirical Research on the Relationship between Audit Costs and Earnings Management. Economic Vision, 6, 83-85.

Zhang, W., \& Wang, H. Y. (2011). Research on the Transmission Mechanism of the Debt Maturity Guarantee Function. Economic Management Journal, 35, 104-111.

Zhang, Y. T., Xiong, Y., \& Zeng, Z. H. (2019). Abnormal Audit Fees and Classified Transfer of Earnings Management: Economic Rent or Audit Cost. Auditing Research, 2, 82-90. 